Article received on: 25th September 2015

Article accepted on: 15th October 2015-

UDC: 78.071.1 Барток Б.

78.02:305-055.2

COBISS.SR-ID 223345676

\title{
Mina Božanić
}

University of Arts in Belgrade

Faculty of Music

Department of Musicology - $\mathrm{PhD}$ studies of musicology

\section{SEEN THROUGH HIS EYES: THE REPRESENTATION OF FEMALE CHARACTERS IN BÉLA BARTÓK'S STAGE WORKS}

\begin{abstract}
The question of gender representation in Béla Bartók's (1881-1945) stage works is discussed through the prism of cultural studies, with reference to the intellectual, social and political atmosphere in which the composer shaped his ideas. In this sense, it is provocative to question how the stereotyped images of women influenced/merged with Bartók's personal view on women, or is it, maybe, possible that one intimate conception of female characters, reflected the composer's specific relationship toward women? The treatment of the female character will be shown through the analysis of the plot and key scenes in Bartók's stage work.
\end{abstract}

Key words: modernism, Judith, The Girl, The Princess, female character, Bartók.

The ideas about human existence, as well as the metaphors of loneliness, womanliness and love articulated the trend of the intellectual milieus in turn-of-thecentury Budapest. This very fertile and complex web of ideas was the central point which drew and united many artists and intellectuals of the time. One of the most influential questions in the intellectual circles of Budapest (but also of every major capital of Europe) was the relationship between man and woman, which shaped all the subsequent debates about human existence and (wo)man's position in the modern society and the world. According to Judit Frigyesi, who

* Author contact information: minabozanic88@gmail.com 
analyzes the intellectual and cultural context in Budapest at the turn-of-the-century, "throughout this time engendered metaphors figured in art and everyday speech in a quite stereotypical manner."1 Most of the intelligentsia considered woman as an 'inferior' and 'subordinate' to man, because of her irrationality, passion, and connection to the prehistoric, animalistic way of life. ${ }^{2}$ The dominant explanation for the relationship between men and women was "the concept that men and women, far from being equal to one another, were in fact polar opposites. Men represented the rational, intellectual and cultural aspects of humanity, while women personified instinct, irrationality and dark primordial forces." 3 Many of the intellectuals of the time, including the poet Endre Ady, the philosopher György Lukács, the writer Béla Balázs and others, did not appreciate the idea of woman's emancipation. They felt intimidated by the fact that women could be their equal in an intellectual (and any other!) sense. ${ }^{4}$ As Frigyesi argues, they were "not at ease with the idea that a woman could take an important role in their development." It is quite interesting to mention B. Balázs' $\mathrm{s}^{6}$ attitude toward the woman and her role in a man's life, because his attitude was rather the norm than the exception. ${ }^{7}$ In his diary entries, Balázs arrogantly wrote about the relationship between man and woman. His thoughts were based on his private experiences with different women in his life, as well as on the ideas that circulated in the intellectual milieus of the time. He considered himself a 'general', a kind of intellectual and emotional pater familias whose role was to guide a woman who would seek his attention, begging and longing for his help and wisdom in the course of life:

They come to me, into the life-observing tower to look around a little bit... and to seek advice and encouragement... They regard me as their general. It is not as though

1 Judit Frigyesi, Béla Bartók and Turn-of-the-Century Budapest, Berkley/Los Angeles, University of California Press, 1998, 196.

2 Ibid., 146, 218. Cf. Stephen Kilpatrick, "'Life is a woman': Gender, Sex and Sexuality in Bartók's The Wooden Prince", Studia Musicologica, 2007, 48/1-2, 164-165.

3 Kilpatrick, op. cit., 164. This attitude toward women was, partially, influenced by Otto Weininger's 1903 book, Geschlecht und Character. Althought Lukács and his contemporaries did not fully embrace Weininger's revolutionary ideas on sex and gender, the very concept of women and men as polar opposites is certainly a reflection of Weininger's ideas.

4 Frigyesi, op. cit., 197.

5 Ibid., 196.

6 The importance of Balázs's attitude is greater considering the fact that he was Bartók's collaborator on the opera Duke Bluebeard's Castle (1911) and on the ballet The Wooden Prince (1917).

7 Ibid. 
Božanić, M., Seen Through his Eyes: The Representation of Female Characters ...

I knew the path but because my faith is stronger and I see things more clearly. ${ }^{8}$ (emphasis M. B.)

His rather arrogant perception of the relationship between man and woman was not unusual for most men, although very few took the liberty to express their opinions, as Balázs did. Another of his diary entries depicts his attitude toward women more clearly:

They are spiritually fresher than men, ethically more restless, expectant, and prepared for something new. Thev are still evolving... ${ }^{9}$ (emphasis M. B.)

'Woman is stupid, but she possesses a deep-rooted instinct in opposition to man's rootless intellect... Woman's security is vegetative and unobvious; she is strong, tenacious, never doubts or hesitates, because her attitude has nothing to do with the certitude of judgement, and therefore alternative possibilities do not even occur to her. She is the force of nature... ${ }^{10}$ (emphasis M. B.)

We can conclude from this paragraph that woman's intellect was limited and guided by her emotions, therefore she reacted impulsively, passionately, and irrationally. She was also very insightful, due to her instinctive nature, and she was capable of receiving man's art. In that sense, woman was desirable as an inspiration for man's work and life - she was a creative force which corresponded to man's rationality. ${ }^{11}$ Woman represented the corporeal world and, consequently, life itself, while man symbolized the intellect and spirit. But, man was doomed without woman, because she possessed a firm grip on reality, and therefore, she could bring him the comprehension of life itself.

Many Hungarian artists drew their inspiration from their love for or their friendship with different women. Such was the case of G. Lukács with Irma Seidler, of Attila József with Márta Vágó, of E. Ady with Adel Brüll, and of Bartók with Stefi Geyer and Emma Gruber. Gruber, Brüll and Vágó were largely responsible for introducing Bartók, Ady and Attila József into the intellectual and artistic circles of Budapest. ${ }^{12}$ On the other hand, Bartók did not have male friends; he considered that friendship between two independent men was not

\footnotetext{
8 Diary, MS 5023/12, 14-15, Manuscript Department, National Széchenyi Library, quoted after: Ibid, 197.

9 Béla Balázs, Diaries, 22 November 1918, Budapest, Akadémia Konnyvtár, s.a., translated in: Mary Gluck, Georg Lukács and his Generation 1900-1918, London, Harvard University Press, 1985, 39, quoted after: Kilpatrick, op. cit., 164.

10 Béla Balázs, Napló 1914-1922, Budapest, Mavető, 1982, transl. in: Gluck, op. cit., 40, quoted after: Ibid.

11 Kilpatrick, op. cit., 164-165.

12 Frigyesi, op. cit., 196.
} 
possible, or was rather rare. ${ }^{13}$ It is quite provocative to reconsider his relationship with Kodály. It can be described as a friendship, although not an intimate one. The two men were bound intellectually and especially ideologically (in their ethnomusicological research and attitudes toward folklore). In fact, if it had not been for this ideological bond between Bartók and Kodály, it would be a question whether they would ever have been friends. Nevertheless, Bartók was aware of the limitations of such a relationship, which is reflected in his rather pessimistic note about friendship between men. He considered that friendship between a man and a woman was likely because in this kind of a relationship one of the two always acts according to the conventions of self-adaptation. ${ }^{14}$

Bartók's rather unsettled attitude toward the women in his life - his mother, sister, Irmy Jurkovics, Stefi Geyer, Emma Gruber, and his future wife Márta Ziegler - was manifested in his personal correspondence with these women. ${ }^{15}$ His opinion that woman could not, in any sense, be a man's equal because she was not supposed to be as rational and strong as a man directly collided with his introvertness and shyness, which acted as an obstacle in his communication with both male and female acquaintances. However, Bartók managed to somehow overcome his shyness in his correspondance with women, especially with Emma Gruber, whereas in his correspondance with men he remained reserved and insecure. Although he felt especially awkward and uncomfortable in the presence of Gruber, who was his senior and of Jewish descendant, she was the only person Bartók could call a true friend. In one of his letters, the composer wrote that he felt ashamed even to call Emma a friend (because of his 'machoistic' attitude toward women, perhaps), but that she certainly was:

'So far, I only have one friend, and sometimes I need some self-deception to call her a friend... In my case too, my only friend is a woman. By the way - she is only a friend!'16

She was the one with whom Bartók could share his intimate thoughts, secrets, and ideas, without fear of being rejected. Bartók's letters to women also contained his aesthetical and philosophical revelations, together with his commentaries about his thoughts, worries, emotions, etc. He never wrote about his emotions to any of his male acquaintances, due to a lack of 'intellectual sophistication and verbal eloquence to carry on philosophical discussions. ${ }^{\prime 17}$

\footnotetext{
13 Ibid., 198.

14 Ibid.

15 Ibid, 145.

16 To Stefy Geyer, 20 August 1907, in Briefe an Stefy Geyer, documet 7, quoted after: Ibid, 198.

17 Ibid., 145.
} 
One of the most interesting facts - which will be of great importance in the question of the representation of female characters - is that Bartók felt the need to open up to a woman he communicated with and whom he considered to be his friend. According to his private correspondence with his mother and his sister, for example, Bartók often had a very gentle and very subtle approach toward them, which was at the same time influenced by his need to be seen as a teacher, tutor, and as guidence for them. The tone of his letters was invariably didactic and simplistic - his "verbal style reflects the assumption that his knowledge of philosophical and psychological matters equipped him to guide these women in such difficult matters [i. e., philosophical and aesthetical debates]." ${ }^{18}$ He would often give them some sort of intellectual assignements to handle, some riddles to resolve, and often he would commend them, if they were successful. ${ }^{19}$ This attitude certainly reveals that Bartók was not immune to the current stereotypical views regarding the man - woman issue. On the other hand, his need to be intimate in a relationship with a woman, to 'subordinate' himself to her, revealing his deepest emotions and thoughts, created a sort of counter-balance to the very stark and bold opinion which arose from the male intellectual circles in Europe. And this circumstance was the most enigmatic one for Bartók himself - he often felt puzzled by the fact that his only friends were women.

This gap between the stark opinion on the man/woman issue prevailing in intellectual circles and his intimate need to bind himself to women influenced the concept of the female characters in Bartók's stage works. But, to what extent did Bartók use his personal attitudes in the creation of female characters? Did his intimate opinion and the stereotypes of women somehow influence the way he depicted his female characters?

\section{Judith, the Princess, and the Girl: 'multifariousness of one'?}

The relationship between man and woman is the ground layer in Bartók's stage works, but the woman is no longer a passive and silent observer, or a gentle and flirtatious member of aristocratic circles, or a troubled and sensitive mother and wife. She is a woman who seduces and charms her man, a woman who controls the course of action, and a woman who is the cause of all the tragic events on stage (and, metaphorically, in life, from the male point of view). It can be said that the representation of female characters ${ }^{20}$ in Bartók's stage works is main-

18 Ibid.

19 Ibid.

20 This section is based on my paper: „Репрезентација женског лика у Бартоковим музичко-сценским делима (опери Замак Плавобрадог и балетима Дрвени прини и Чудесни Мандарин)“, у: Ивана Перковић (ур.), Музиколошка мрежа/музикологија у мрежи, 
tained in an expressionistic manner: the female character has the leading role in the work, acting (almost) independently in the context of the dramatic action and confronting the masculine enviorenment where she is positioned.

The reflection of current ideas about the relationship between man and woman that circulated through the arts at the beginning of the $20^{\text {th }}$ century can be identified in two dominant models in the representation of the female character in Bartók's stage works. ${ }^{21}$ The first is the stereotype of the femme fatale, which emerged during the fin-de-siècle period in arts. ${ }^{22}$ The most common image of this stereotype was Salome, a young, beautiful, sensual and dangerous woman. The image of Salome was often misidentified with the image of Judith, who was depicted as "a young woman of considerable sexual allure." 23 Judith/ Salome was seen as a woman who made men fall in love with her, which resulted their most violent death. This type of woman could defeat men with her physical appearance and beauty, so men were intimidated by her presence. "Judith and Salome were symbols of the women men feared, women whose physical attractiveness enabled them to wield enormous power over men." 24

The second model can be called the "woman is life" model. As Stephen Kilpatrick has shown, the opinion that woman breeds life into man's ratio and his art was not uncommon for Bartók's circle. ${ }^{25}$ The intuition and primal instinct which woman possessed were what man needed in his life. Paradoxically, the acceptance of woman symbolically meant the death of man, and subsequently his despair, because he could never be intellectually fulfilled and free once he fell into a woman's arms.

зборник радова студената музикологије, св. 5/2014, Београд: ФМУ, 2014, 261-291, http:// www.fmu.bg.ac.rs/fmu/elektronska\%20izdanja\%20studentski\%20radovi.html.

${ }^{21}$ Althought it would be very provocative to explore the representation of the female character in visual arts or in other stage works from the same period of time, it cannot be done in this study. However, it can be noted that Bartók's female characters are not isolated from the female characters in, for example, Gustav Klimt's paintings Judith I (the full title of the painting is Judith beheading Holofernes, 1901) and Judith II (1909), or from Arnold Schoenberg's Frau in the monodrama Erwartung (1909), or Igor Stravinsky's Girl in The Rite of the Spring (1913).

${ }^{22}$ For useful debate over the issue of the representation of the female in the fin-de-siècle arts and literature cf: Carl S. Leafstedt, "Judith in Bluebeard's Castle: The Significance of a Name", Studia Musicologica Academiae Scientarium Hungaricae, 1995, 36, 3/4, 429-447, www.jstor.org/stable/902224, accessed in December 2010.

23 Ibid, 430.

24 Ibid.

25 Kilpatrick, op. cit. 
It is challenging to analyze how these two models shape the female characters in Bartók's stage works, because they directly rely on the cultural and intellectual climate in which the composer participated. However, these models are not present as autonomous or exclusive in one or more female characters; in fact, they coexist in one or more characters, and the fact that one model prevails over the other is the result of the context in which these female characters appear and act. In that sense, I would trace the manifestation of these models in the characters of Judith, the Princess, and the Girl, analyzing the relationship between the male and female characters in a chosen work, both in the text and in the music. My analysis aims to show how the composer's personal attitudes and the contemporary cultural climate interrelated with the arts, especially with the issues of gender representation.

The character of Judith from Duke Bluebeard's Castle (1911) is concieved on the image of Judith/Salome, and this model clearly dominates the representation of this character. There are very few scenes where we can see Judith being gentle or subordinate to Bluebeard. And when we do see her like that, she has already accepted her destiny. For the most part of the opera, Judith is depicted as a physically attractive and desirable young woman ${ }^{26}$, but also as aggressive and persistent in her intentions, and most certainly willing to obtain some sort of control over Bluebeard and his castle. At the beginning of the opera, Judith seems frightened, insecure, and in love with Bluebeard. Musically speaking, her part is sung dolce and piano, and she only answers the questions Bluebeard asks. (See: Ex. 1) Although her love for Bluebeard is not captured in the libretto, she definitely has feelings for him. She left the security of her parental home, "the patriarchal protection of her father, her brothers, and her betrothed" 27 to pursue happiness with the mysterious Duke Bluebeard. In that sense, it can be said that Judith, in a way, loves Bluebeard and that her actions are the result of her childish, naive love for an older man. ${ }^{28}$

If Judith was insecure at the beginning of the opera, she gradually liberates herself and becomes aggressive, ambitious and curious. Her vocal part becomes more complex throughout the opera, expanding both motivically and dynami-

\footnotetext{
26 Some authors, like David Cooper, would argue that Judith is represented as a virgin, or girl in her teen years. David Cooper, "Béla Bartók's Duke Bluebeard's Castle: A Musicological Perspective", in: Griselda Pollock and Victoria Anderson (Eds.), Bluebeard's Legacy: Death and Secrets from Bartók to Hitchcock, New York, I.B. Taurus, 2009, 58.

27 Elliot Antokoletz, Musical Symbolism in the Operas of Bartók and Debussy: Trauma, Gender, and the Unfolding of the Unconscious, Oxford, Oxford University Press, 2004, 48.

28 David Cooper insists on this relationship between the young Judith and the older Bluebeard. His interpretation relies on the Freudian analysis of the father - daughter relationship. Cooper, op. cit., 58, 64.
} 
cally. Soon after entering the castle, the game of door opening begins, and in this game we can trace the development of Judith's character from the naive and insecure maiden to the obsessive and frustrated woman. She gradually becomes more and more curious and ambitious, thinking that for a moment she could easily win this game and prove all the rumours she has heard about her husband and his previous life are true. At first, she reluctantly opens each door, therefore she reveals the secrets of her husband's character. ${ }^{29}$ She calmly observes each room, and her interest in opening the door increases, while Bluebeard starts to question his decision to let Judith know his secrets. When she feels Bluebeard is questioning himself, Judith becomes very seductive, using her body as a means to fulfill her goals. This latent eroticism is not further developed in the opera, but it is important for the character of Judith, and the characters from Bartók's ballets. However, Judith's eroticism is suppressed, thus becoming the source of her frustrations. As she yields to her husband's attentions, he remains cold and distant, incapable of satisfying her physically. Judith's desire to explore the secrets of her husband's castle gradually expands, until the point where she realizes that there is no turning back. Even when Bluebeard begs her just to love him and not ask questions about his past, she cannot respond to this. The sudden shift that occurs in the fifth door scene brings a radically different Judith into the focus of the drama. (See: Ex. 2) The new Judith is more silent, almost insensitive, and extremely passive. It seems that the end of the drama is set in this very scene, and that it cannot be overcome. However, Judith remains persistent in her intention to reveal the true nature of the man she has married, but her desire for the truth results in a dramatic twist. Instead of confirming the rumours about Bluebeard's previous wives, Judith finds out that the rumours were nothing more than that. But, she must be punished for her arrogant desire to reveal Bluebeard's secrets. Therefore, she becomes the fourth wife behind the seventh door, leaving the eternal darkness behind.

In portraying this female character, Bartók used original and 'gendered' musical means. The male and female characters in the opera are musically differentiated: the male character is represented through the diatonic material, while the female character is represented by the chromatic or whole tone material. This distinction clearly relies on the current sexist and gendered debates over the role of man and woman in contemporary society. In this sense, the female character

29 The content of each room goes as follows: the first door reveals the torture chamber, which denotes Bluebeard's cruelty; the second door discloses Bluebeard's armory, representing his strength; the third door reveals his treasury, indicating his wealth. Behind the fourth door lies the garden; the opening of the fifth door reveals Bluebeard's kingdom. The sixth door unveils the lake of tears, alluding to Bluebeard's sensitive side. Finally, the seventh door holds his biggest secret - his previous wives. 
is portrayed as 'alien' to the male character, which corresponded to Bartók's (and not only his!) machoist opinion that woman is strange to man and his world. The woman is seen as an intruder, as someone who is not desirable in the male's 'castle', and especially not allowed to wander so freely around that castle and to ask questions in order to influence a man's autonomy.

On the other hand, the character of the Princess from the ballet The Wooden Prince is articulated by the 'woman is life' model. This model, in a way, is a philosophical reflection of the idea about man and woman, and her features are not so sharp and distinctive as in the case of the femme fatale model (which has its roots in the literature and the visual arts of the $19^{\text {th }}$ and $20^{\text {th }}$ centuries). Because of its philosophical nature the 'woman is life' model is very illusive and may not be so evident as the femme fatale model, but it nevertheless dominates the representation of the Princess.

The Princess is represented as a very passive, flirtatious, and vain woman. Unlike the Judith from the opera, the Princess is subordinate to the Prince. The whole plot is, in fact, focused on the Prince, and not the Princess. Her role is rather secondary and not so detailed as the role of Judith or the Girl. However, in the moment when the Princess is supposed to choose between the prince and his alternative, the wooden prince, she comes into focus in the dramatic action. It is at this very moment that she becomes active, but only to liberate her selfishness and superficiality. She chooses the wooden prince, falls in love with him and starts to seduce him. She enjoys dancing with the wooden prince while the real prince remains in despair. However, the wooden prince falls back into lifelessness, and the ballet ends with the Prince and the Princess in love.

In the musical characterization of the Princess, Bartók uses familiar means, at least compared to the portrait of Judith. The idea of dance is quintessencial for the character of the Princess, because through the dance she reveals her femininity, her seductiveness, and her sensuality. (See: Ex. 3) In the portrait of the Princess, Bartók also explores the idea of 'woman being alien to man' - the musical material that goes with the character of the Princess is understood as 'strange' in comparison to the musical material of the Prince. Her theme is associated with the verbunkos tradition, which was often interpreted as something 'not pure', and consequently does not correspond to the 'true' Hungarian folklore tradition. It is quite interesting to note that the theme is exposed in the clarinet part, considering the fact that this instrument was a symbol of 'non-pure' verbunkos and Gypsy tradition. ${ }^{30}$ The melody moves aimlessly, referring to the Princess's shal-

30 Cf. David E. Schneider, Bartók, Hungary, and the Renewal of Tradition: Case Studies in the Intersection of Modenity and Nationality, Berkley/Los Angeles/London,University of California Press, 2006, 129 et passim. 
lowness. In the Princess's first dance scene, we can trace a waltz with the rhythm of a polonaise, which Bartók uses ironically - the Viennese waltz represents kitsch. These foreign-style mixtures David Schneider sees as an original means to epitomize the Princess's superficial and vain nature, as well as to set the stage for her misguided attraction for the wooden prince. ${ }^{31}$

However, the most provocative conception of the female character in Bartók's stage works can be found in the character of the Girl from the ballet The Miraculous Mandarin (1919). Unlike the character of Judith (with its strong Biblical roots) and the character of the Princess (which is rooted in the fairy tale tradition), the character of the Girl is taken from real life. She is a prostitute in a metropolis, a lost individual who is struggling in life and seeking true love. Another aspect of this character is her pursuit for her identity, that specific and special inner voice which would distinguish her from the very impersonal and dull crowd she is currently living in. On the other hand, the character of the Girl explores the idea of bodily movement in a most extreme way, partly because of the fact that she is a prostitute, using her body to seduce and lure potential clients. In that sense, we can trace the model of the femme fatale in the representation of this character. But, interestingly, this model gradually becomes overwhelmed by the universal idea of human loneliness in the metropolis. In that way, this female character becomes something more that just a female - the Girl from The Miraculous Mandarin becomes the symbol of the lonely human being, trapped in a loud, unfriendly and unpleasent urban enviorenment, searching for their inner voice and their inner self. And, the only thing that such an individual can seek is a primal force, related with the character of the Mandarin. ${ }^{32}$

Her pursuit for this inner voice begins with a confrontation with three tramps, who force her to lure men so they can rob them. After this brief and musically intense first scene, the Girl unwillingly starts to dance, in order to attract the attention of potential clients. The first seduction game clearly reflects this unwillingness - the melody (again in the clarinet part!) is rigid, its ambitus is small, and one can sense a certain dissonance in it. It is like the melody moves unwillingly of itself, reflecting the Girl's emotional state. After the unsuccessful first seduction, the Girl begins the second. However, she is not as rigid as in the first seduction game: she starts to feel comfortable in the act of seducing. It can be argued that she gradually accepts her femininity, her sensuality and her physical attractiveness, and it is most clearly represented in the second seduction

31 Ibid., 130.

32 In spite of the very provocative ideological backround of this ballet and various possible meanings of its text and music, my discussion will not address it in detail. Cf. Ibid., 141 et passim. 
game. The melodic movement in the second seduction game is more flexible and more fluid. The perfect fifth (which was present also at the beginning of the first seduction game) gains a more "natural" tone. ${ }^{33}$ The culmination of the Girl's seductiveness and femininity appears in the third seduction game, which is dedicated to the Mandarin. The relationship between the Girl and the Mandarin is rather unusual in the context of Bartók's stage works. Firstly, there is no musical polarization between the male and female characters: ${ }^{34}$ on the contrary, the thematic material of the Girl anticipates the thematic material of the Mandarin. (See: Ex. 4) Secondly, the Mandarin, unlike other male characters, represents the Other, regarding his decendent and the cultural discourse represented in the ballet. This could be the reason why the composer unites the Girl and the Mandarin: they both represent the Other - the Girl in relation to other male characters, and the Mandarin in relation to the Western discourse. Upon that foundation, it is quite possible that Bartók saw the Girl as an individual trapped in a metropolis, not as a woman. This conception of the female character in his last stage work clearly digresses from the conception of the Judith or the Princess. In that way, the Girl becomes a symbol of human loneliness and existance in the modern world, that is - she rises beyond the gender categories.

\section{Conclusion}

The cultural atmosphere which resonated with the current social and political events at the beginning of the 20th century most certainly influenced the course of various artistic activities in all major European centres. At this specific moment, questions arose about human existance, loneliness, and alienation. However, one of the most influential was the question of the relationship between man and woman, which served as an inspiration to many artists, poets, and thinkers of the time. In this sense, it seems very provocative to explore the idea of gender representation in the arts, especially in music. Bearing in mind that gendered

33 Stephen Downes, Eros in the Metropolis. Bartók's The Miraculous Mandarin, Journal of Royal Music Association, 125, 1, 2000, 50, www.jstor.org/stable/3250681, accessed in December 2010.

34 Schneider argues that the relationship between the Girl and the Mandarin echoes the relationship between the Prince and the Princess: both couples are musically set against the backdrop of a metropolis in the case of the Girl and the Mandarin, or nature, in the case of the Prince and the Princess. This polarization, which goes beyond the polarization between the male and female characters, is a basis for the dramaturgical conflict in both works. Schneider, op.cit, 141. However, the Girl and the Mandarin are not musically differentiated, as was the case with the previous works, where the female character was associated with chromaticism or the verbunkos tradition, while the male character was associated with diatonicism. 
metaphors floated around in the discourse of manifold intellectual and artistic circles, it is imporant to show how the members of these circles reacted and contemplated the questions of gender relations. One can trace two most common stereotypes on woman in Hungarian (and European!) art. One of them was the stereotype of the femme fatale, which was materialized through the representation of Judith/Salome. The other is the model "woman is life", which was drawn from the aesthetics and philosophy of Nietzsche and Kierkegaard, and explored by György Lukács.

Where does Bartók position himself, according to these circumstances? As J. Frigyesi has shown, ${ }^{35}$ Bartók's personal attitude toward women was partially rooted in the sexist and chauvinistic debates that dominated the circles in which he moved. He did believe that woman's place was beneath man, namely, that woman is subordinate to man in the intellectual and emotional sense. On the other hand, his introvertness and shyness in his communication with both male and female acquaintances resulted in his choice to open up to the female ones. Although he never would admit that a woman could be his only friend, Bartók undoubtelly felt more secure in his communication with them.

The most striking feature of Bartók's works is definitely the female character. It is shaped according to Bartók's intimate attitude toward women and the current stereotypes on woman that circulated in the arts in the first half of the $20^{\text {th }}$ century. In fact, the female characters in Bartók's stage works emerge in a very specific 'space': they emerge at the intersection of the cultural and intellectual atmosphere of the time and the composer's personal attitudes toward women. These two different and somewhat exclusive opinions about women resulted in the very unique representation of his female characters. All three of them Judith, the Princess, and the Girl - are young, beautiful and sensual women, who act freely and sometimes dominate their male partners. This domination can be seen in the number of appearances in the course of the musical work, or in the musical material employed in their characterization. In that sense, Judith and the Girl are the most dominant ones: ${ }^{36}$ Judith has a considerably larger number of appearances than Bluebeard, while the Girl is the central character in the ballet. On the other hand, the idea of dance is incorporated in the characters of the Princess and the Girl, while the character of Judith rests upon the idea of latent eroticism (she only speaks about using her body). The idea of dance clearly des-

35 Frigyesi, op. cit.

36 It is interesting to note that both works, Duke Bluebeard's Castle and The Miraculous Mandarin, are named after the male character, althought the female character is definitely more present in the work. Does it mean that Bartók was not ready after all to fully grasp the idea of equality between man and woman? 
ignates the sensual and erotic feature of these characters, and it most certainly confirms the expressionistic mode of gender representation.

The musical polarization between the male and the female character in the opera and the ballet The Wooden Prince is manifested through the use of chromatic or whole-tone material (in the case of Judith and the Princess), in contrast to the pentatonic or diatonic material (in the case of Bluebeard and the Prince). This differentiation denotes the idea that the woman is the intruder, therefore setting the role of the woman as inferior to the man. But, the character of the Princess brings forward the possibility of accepting the woman as she is, namely her instinct, irrationality and intuitiveness as something man has missed. To accept the woman means to renounce his freedom and autonomy, but also the beginning of an emotionally and creatively fulfilled life.

On the other hand, the Girl from the ballet The Miraculous Mandarin considerably differs from the characters of Judith and the Princess, because she has the opportunity to comprehend her identity, and to find true love. The passion represented in the character of the Mandarin is the primal indicator of the Girl's comprehension of her inner voice and, one could say, her own femininity. The way Bartók shaped this character represents a new approach to the female character in his works. The fact that he treats the Girl as an individual, not as a woman leads to the conclusion that women, too, deal with the problems of loneliness and alieniation as men do. And this most clearly releases them from any gendered metaphors, because the problem of living in the modern world knows no such classification - there are just individuals in search of their own meaning in life, and in search of love. 


\section{Appendix}

Example 1: Béla Bartók, Duke Bluebeard's Castle, Judith’s first appearance, mm. 39-43.
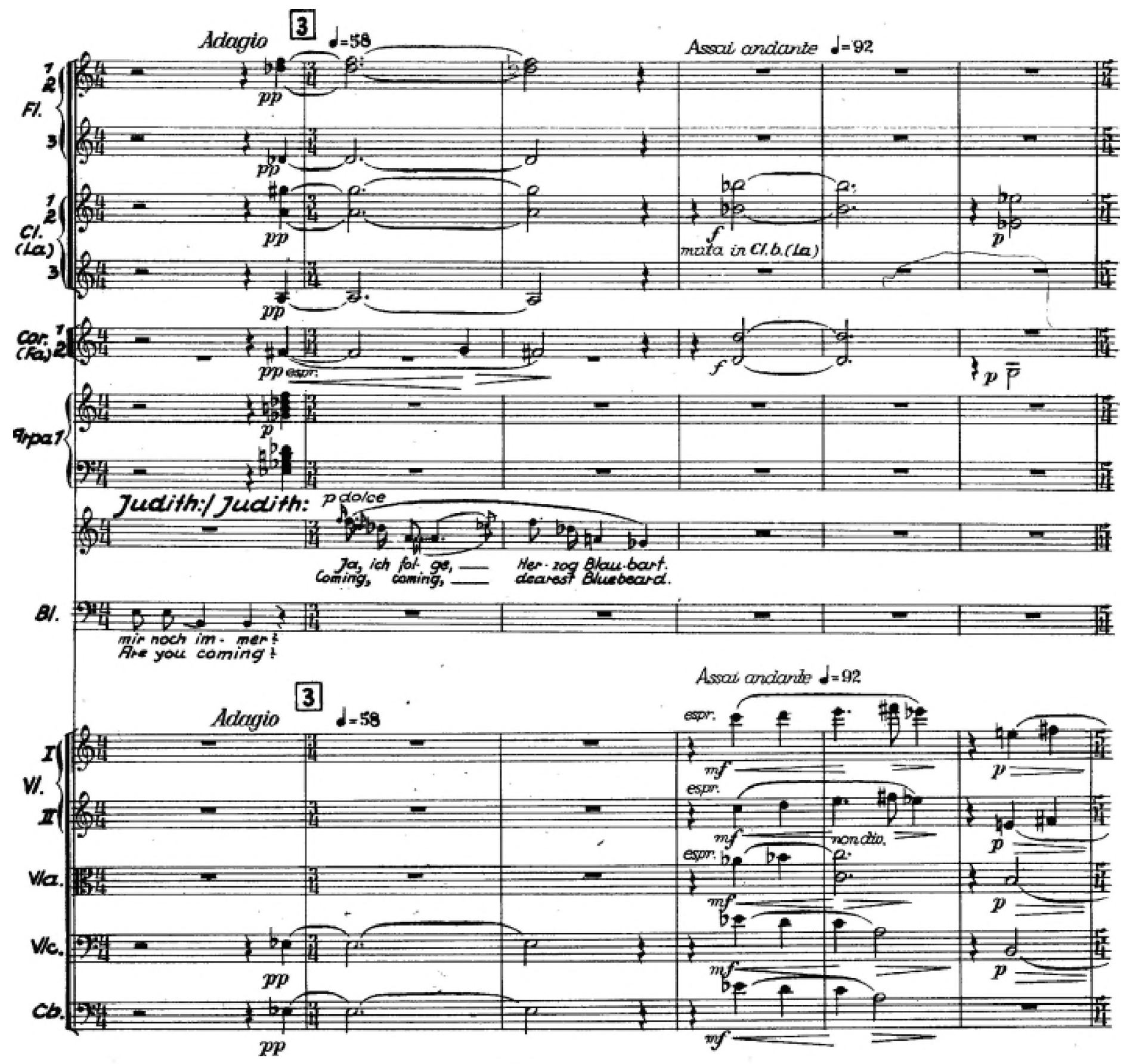

Example 2: Béla Bartók, Duke Bluebeard's Castle, Judith's part in the fifth door scene, m. 776.

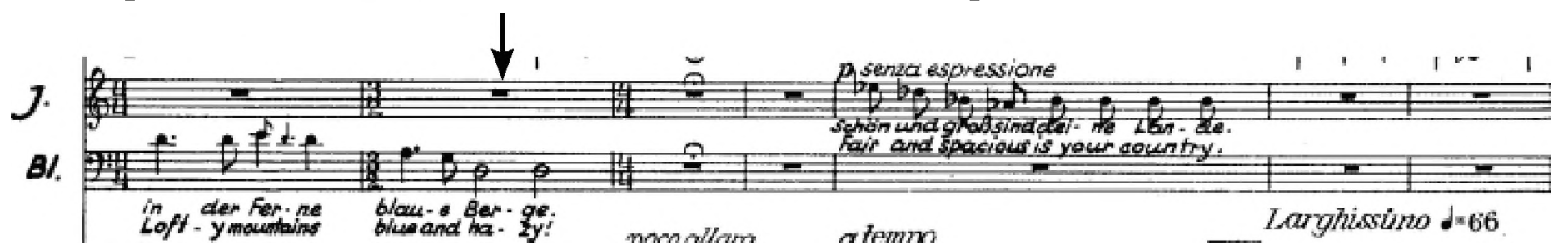


Božanić, M., Seen Through his Eyes: The Representation of Female Characters ...

Example 3: Béla Bartók, The Wooden Prince, the Princess's dance, no. 11.
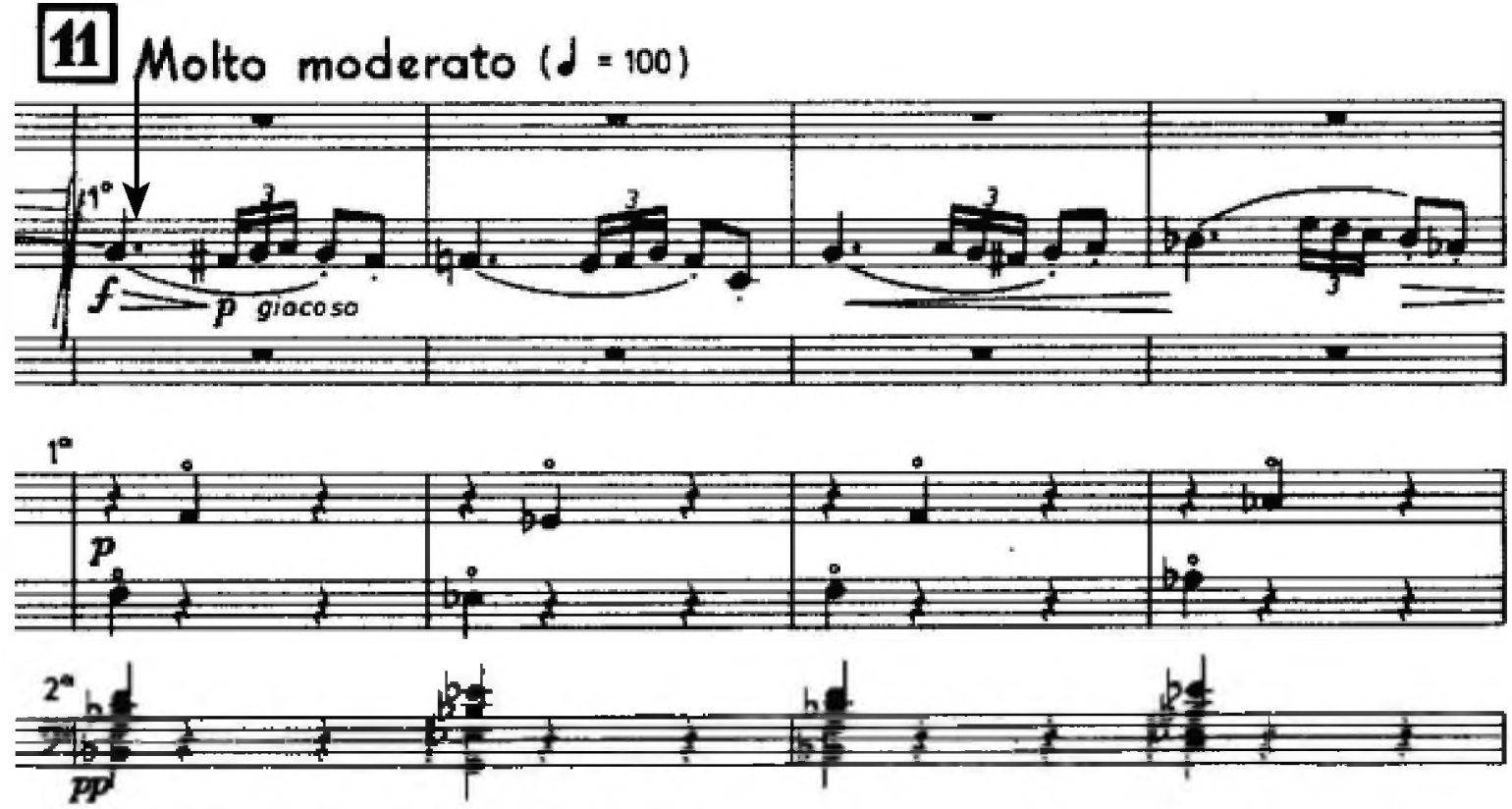

I.Tanz: Tanz der Prinzessin im Waldz

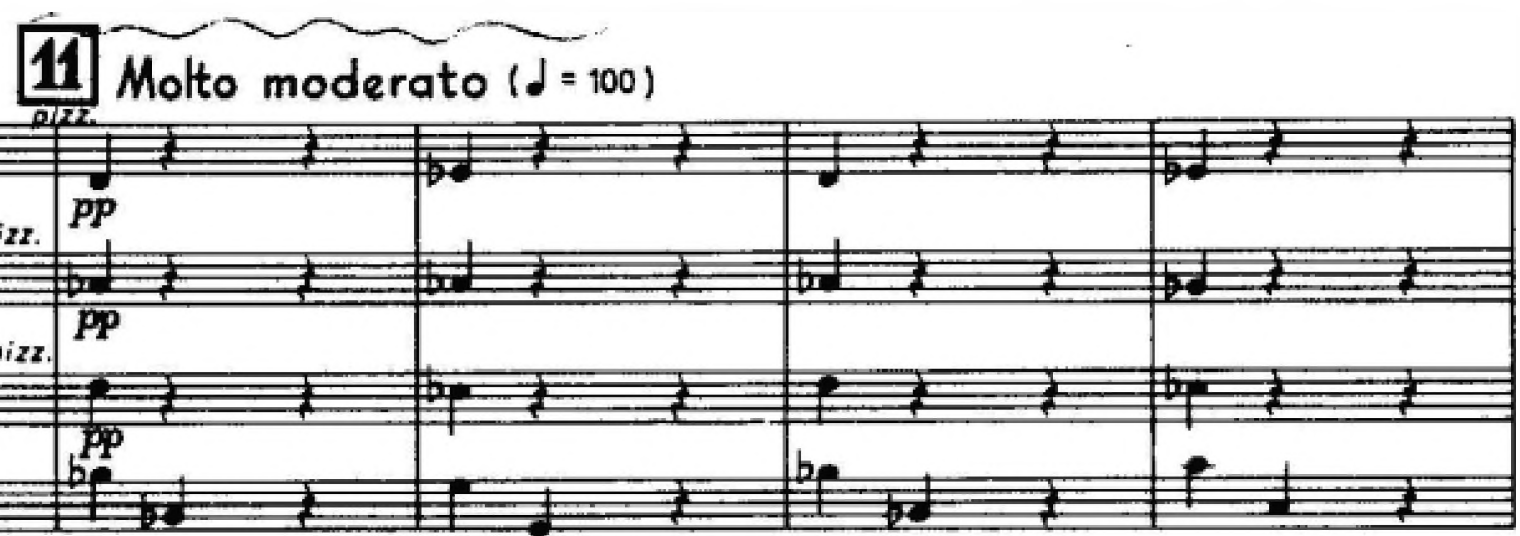

UE 6638

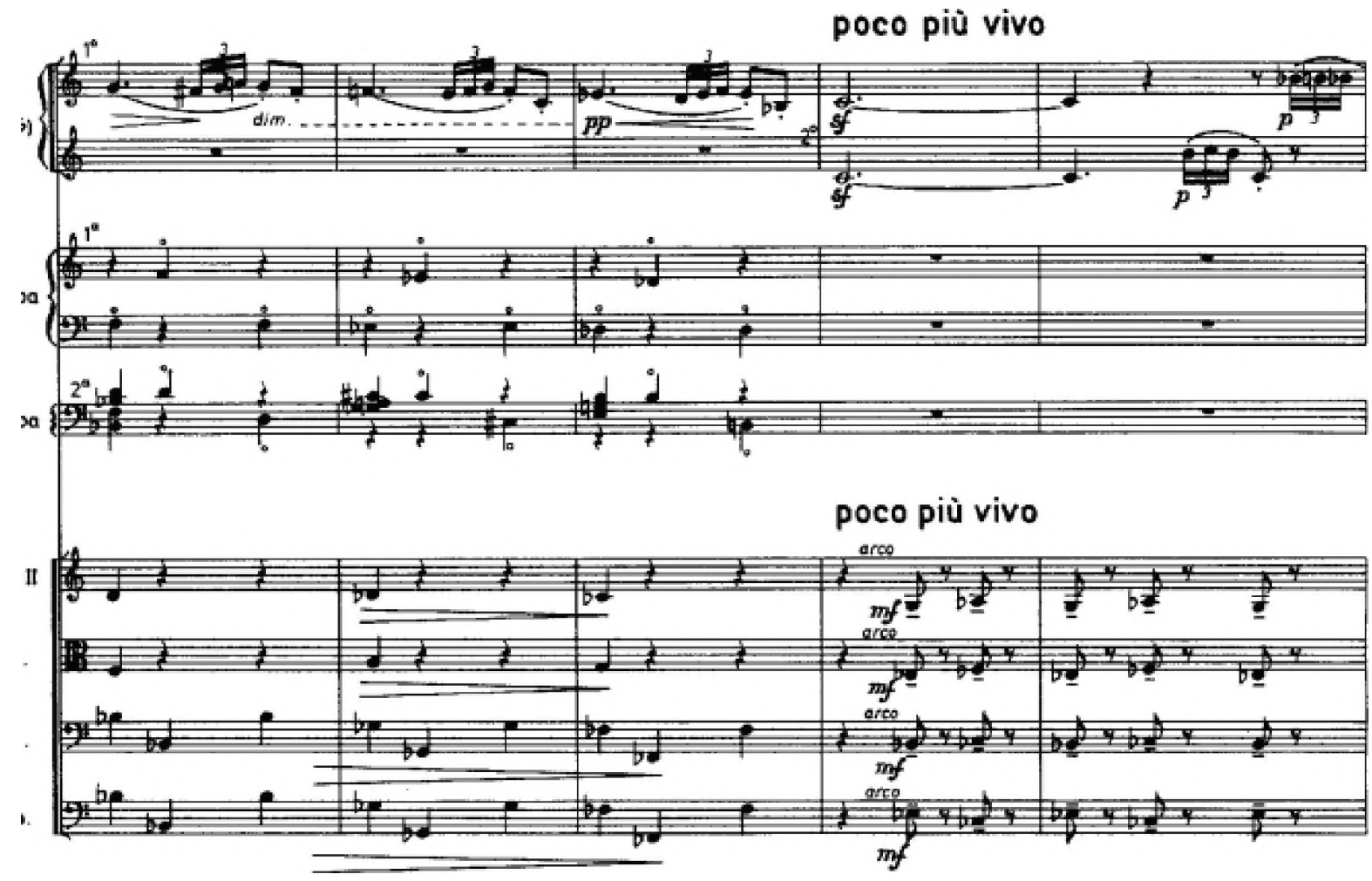


Example 4: Béla Bartók, The Miraculous Mandarin, the third seduction game, 3m. before no. 31 ..
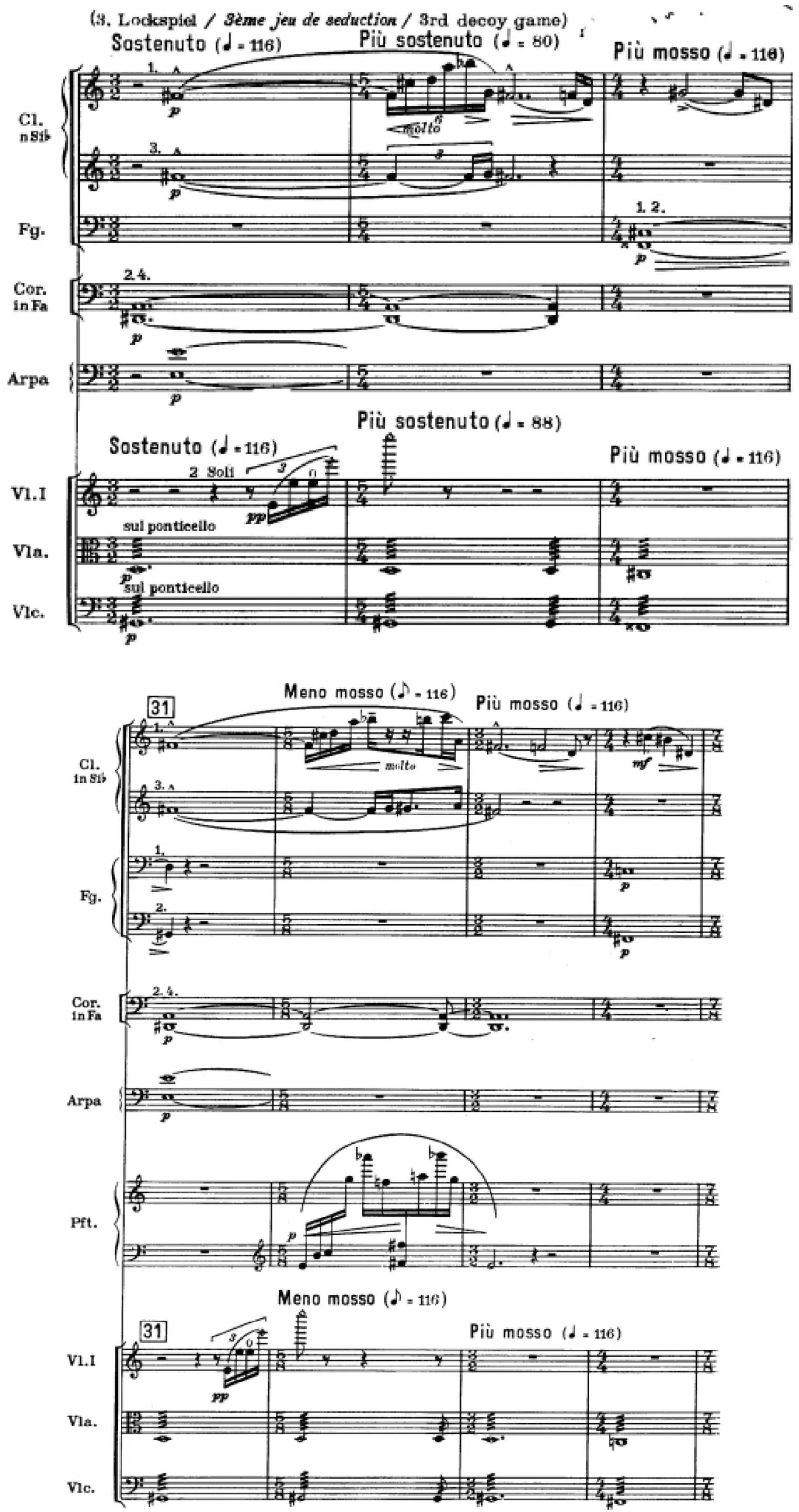